\title{
Macroeconomic Policy, Labour Markets and Growth in Developed and Developing Countries
}

\author{
John Toye
}

\author{
1 Introduction \\ The point of departure for a discussion of what \\ macroeconomic policy can or cannot do depends on \\ the economic context. In the real world, assuredly, \\ there are hundreds of different economic contexts. \\ That is why one size of macroeconomic policy does \\ not, and cannot, fit all. Purely for expository \\ purposes, however, this article shall distinguish just \\ two archetypes of economic context, 'developed' \\ and 'developing' countries. 'Developed country' here \\ means one in which (1) the economy is fully \\ monetised; (2) wage employment is the dominant \\ form of employment; (3) institutions of free \\ collective wage bargaining are in place; and (4) social \\ protection exists for workers' stochastic risks - job \\ loss, industrial accident, ill health and incapacity in \\ old age, but not for the co-variant risk of mass \\ unemployment. 'Developing country' here means \\ one where (1) the economy is less than fully \\ monetised, because subsistence and barter economy \\ still prevails in part; (2) wage employment is a \\ minority form of employment, the dominant form \\ being self-employment with associated low levels of \\ capital per head and low levels of labour \\ productivity; (3) institutions of free collective wage \\ bargaining, if they are in place, have a restricted \\ impact on conditions of employment; and (4) social \\ protection against stochastic risks is very limited, \\ even for the minority who are wage workers. One \\ can think of these two stylised contexts as the \\ extremes of a spectrum. Most real world contexts \\ can be found somewhere between these extremes. ${ }^{1}$ \\ This article begins with the analysis of the \\ 'developed country' archetype. Then, in the second \\ half, the article turns to the 'developing country' \\ archetype.
}

\begin{abstract}
2 Labour markets, macroeconomics and employment policy in 'developed countries' Where did macroeconomics come from? Why is it necessary at all? Before the publication of Keynes' General Theory in 1936, employment was analysed by looking at separate labour markets - the markets for the services of butchers, bakers and candlestick makers. Lionel Robbins' Theory of Wages (1934) was the classic statement of this approach, in which total employment was the sum of employment generated in each labour market by the forces of supply and demand for labour services operating there. The recommended employment policy was to permit wages to fluctuate freely, so that each labour market cleared, because there was thought to be no form of government intervention that could improve on that outcome.
\end{abstract}

Keynes invented his macroeconomics (his general theory of employment, interest and money) in order to demonstrate that, when one considers aggregate demand for output, and its derived aggregate demand for labour, and the aggregate supply of the factors of production, capital and labour, the policy recommendation of non-intervention did not hold. His basic intuition was that there were interactions between apparently separate labour markets and apparently separate markets for goods. When the wages of candlestick-makers declined, so did their demand for the products of butchers and bakers, who found that they were accumulating excess stocks. Fewer butchers and bakers would then be employed, further reducing the demand for candlesticks. This employment multiplier effect, if taken into account, showed that market forces tend to intensify any negative shock to employment. Keynes further 
showed that, given certain assumptions about the response of investors to the interest rate and the money supply, either (a) the economy can reach a short-run equilibrium position where some unemployment is involuntary, i.e. where some workers would prefer to work at the prevailing wage, if they could; or (b) the economy remains in a permanent disequilibrium of underused resources. ${ }^{2}$ In either situation, he argued, it would be justified for the government to intervene in order to add to aggregate demand. ${ }^{3}$ It should continue do so until the economy reached full employment. Thus Keynes overturned the recommendation of government inaction.

The difficulty with this active employment policy is that it is not easy to define what is meant by aggregate full employment. Keynes gave this definition:

We have full employment when output has risen to a level at which the marginal return from a representative unit of the factors of production has fallen to the minimum figure at which a quantity of the factors sufficient to produce the output is available.

(Keynes 1978: 15-16)

His definition implies that the marginal disutility of labour (i.e. the labour supply constraint) is what sets the upper limit to potential output. So Keynesian macroeconomic theory included an upper bound on aggregate employment, beyond which further increases in aggregate demand produce no extra output, but merely cause a rise in the general level of prices. However, in practice it was very hard to identify this upper bound to employment. The concept of the marginal disutility of labour is of very little use to practical policymakers, not least because the marginal disutility of labour itself depends on one's level of real income.

Keynes sometimes settled for the more prosaic notion that full employment meant that everyone who wanted a job had one. That raised the question of what is meant by 'a job'. Even in developed countries, where wage labour is the dominant form of employment, jobs are not homogenous. The required hours of work differ; the nature and intensity of effort differs; the payments and rewards systems differ. In addition, a minority form of employment is self-employment, in which each individual attempts to set their tasks, regulate the quality of performance and set the price to be charged for it. Given this variety, what could 'full employment' mean? Joan Robinson quickly perceived the difficulty and that, using the criterion of labour productivity, some forms of selfemployment might be seen as being 'disguised unemployment'. Her favourite example of this was of the match-seller in the Strand (Robinson 1962: 86).

In developed countries, this vagueness about the point of full employment fed into an important policy problem, of which Keynes was certainly aware. A government committed to maintaining full employment within a free wage bargaining system would sooner or later generate an inflationary spiral. The unemployment of candlestick-makers that would otherwise be caused by their union's success in raising their money wages would be eliminated by the policy of maintaining a high level of aggregate demand. Since there was no longer any unemployment penalty for pushing up money wages, the butchers' and bakers' unions would press for compensating wage increases. A general rise in the level wages would raise the general price level, which would raise wages, and so on. This indeed turned out to be the economic experience of many developed countries that followed neo-Keynesian policies in the 1960s and 1970s. In 1975, for example, Britain had an inflation rate of 15 per cent and the government introduced price controls and subsidies on loaves of bread.

\section{Inflation targeting and public expenditure planning in developed countries}

Since those days, the institutions of macroeconomic policy in many developed countries have been reformed to improve the management of inflationary expectations. Reforms include allowing central banks 'independence' to control monetary policy, thereby removing from politicians the temptation to buy short-term social peace at the expense of long-term inflation, and the setting of a precise inflation target at a low positive level in place of an inevitably imprecise employment target. These reforms have impacted favourably on the machinery for planning public expenditure. Public expenditure comprehends shoes and ships and sealing wax, and cabbages and kings - plus all the public sector's spending on social security measures. The planning of public expenditure is thus necessary, although obviously not sufficient, for the effective delivery of health, education and social support services. 
Best practice in the planning of public expenditure now takes place by projecting the framework of the national accounts, based on (a) forecasts of key parameters and (b) the observance of two selfimposed constraints. The parameters that are forecast are: the future growth rate of the economy; the likely yield of major direct and indirect taxes; and of the future course of interest rates, which affects the cost of servicing government debt. Additionally, the expenditure totals have to satisfy two constraints, or fiscal rules. One applies to the national accounts category of current spending, and the other applies to the national accounts category of investment spending. On current spending, 'the golden rule' is that, over the economic cycle, the government will borrow only to invest, and not to fund current spending. This means that, over the economic cycle, current spending must not exceed current revenue. On investment spending, 'the sustainable investment rule' is that, over the economic cycle, public sector net debt will not exceed 40 per cent of GDP. ${ }^{4}$ Taken together, the forecasts and the observance of these two fiscal rules as constraints sets the upper limit for the projection of total managed expenditure.

The underlying forecasts now have to be audited by an independent agency, which has to judge whether they are well-founded and prudent. This judgement must be made public, to prevent the government from making unduly favourable growth, tax yield and interest rate forecasts simply in order to justify excessive public spending. Moreover, the question of whether or not the fiscal rules have been complied with also has to be verified independently by another agency. The adoption of these safeguards has curbed the political manipulation of the planning numbers.

The delegation of the task of inflation control to an independent central bank results in an important simplification of the task of planning public expenditure. This measure formalizes the government's commitment to maintaining a low inflation rate, by giving the central bank discretion to use monetary policy to hit the low inflation target. It removes the temptation for a government to add to inflationary pressures in its wage bargaining, because doing that would trigger interest rate rises that would raise the cost of its own borrowing. It also removes the opposite danger, that a government would use cash limits on public spending in order to achieve a pre-determined target level of pay settlements for those who work in the public sector, including those who provide social protection as employees of the health and social security services. If, by such methods, inflation can be kept to low annual percentage rise, it becomes easier to forecast future interest rates, and makes it possible to adopt a public expenditure planning system based on constant prices, simply because the difference between expenditure at current and constant prices will be kept very small.

\section{Macroeconomic dynamics and economic growth}

Keynes's general theory of employment was concerned with the short run period of one year to 18 months. The original policy problem about the macroeconomic dynamics of growth was how to maintain full employment over the long run, the period when the size of the labour force changes as a result of population growth, and saving behaviour, assumed to determine investment behaviour, might also change. If technology were assumed to be unchanging, there seemed to be a problem of knifeedge instability, which could lead to a severe crisis of contraction in a developed economy as it grew (Harrod 1951).

The neoclassical growth model, due to Robert Solow and Trevor Swan, proposed to resolve this problem by allowing the technology of production to vary. The strategic modification of the Harrod-Domar model was to change the capital-output ratio from a constant to a variable. The central question of policy thus became, how is this choice of capital intensity to be made? Solow assumed that the choice would be taken by competitive entrepreneurs in a decentralised competitive market system, although the features of these markets, including the labour market, do not appear in the model. The growth rate of labour, for example, is assumed to be the same as the growth rate of population. ${ }^{5}$

The economists of Cambridge (UK) criticised the Solow-Swan model, questioning the possibility of valuing a heterogeneous set of capital goods when interest rates vary, and thus the validity of the claim that the interest rate is determined exclusively by the declining marginal productivity of capital, a feature valid only in a one-commodity model. Underlying this technical critique was an alternative vision of the economy in which profit-making decisions of capitalist firms are the driving force, and the 
fundamental economic problem is the allocation of surplus output to ensure reproduction and growth. In such an economy, consumers are not sovereign. Rather, individual worker-consumers occupy a variety of positions of subordination, according to their class places in the division of labour. The labour market assigns individuals to a hierarchy of occupational roles. These roles are stratified by economic reward, social recognition and political empowerment. The differentiation of labour rewards is decided by the relative bargaining strength of the individual employee and of shareholders of the firm or their managers. Legal property rights allow the firm to appropriate the surplus from production, after paying out labour rewards. The saving and spending behaviour of the different social classes and the animal spirits of the investing capitalist firms are the determinants of the rate of profit. However, this alternative account of how the capitalist system works had little impact on macroeconomic policy.

\section{Labour markets, macroeconomics and} employment policy in 'developing countries' Joan Robinson widened her claim that the match seller in the Strand was manifestation of disguised unemployment to include its equivalent in developing countries - the peasant in India whose land holding was too small to keep the whole family busy. ${ }^{6}$ Agricultural employment provides the greater part of all employment still in many developing countries and much of this employment is still family-based, non-monetised and subsistenceoriented. Here, as Arthur Lewis noted, 'everybody has some sort of a job, however great the pressure of population' (Lewis 1966: 76-7). In the rural areas, land gets sub-divided, but the shrinking farms do not shed their labour in order to preserve the claim of all family members to a share of the produce. In the urban areas, the better-off have a social obligation to hire domestic servants - cooks, cleaners, gardeners, drivers and so on. Those who cannot get such positions fall back on petty trading and small scale manufacture in the informal sector. The returns to family farm labour, domestic service and informal activities are very low. Occupations or livelihoods within all three segments of the economy tend to be allocated by personal patronage, rather than by impersonal labour markets.

The poor articulation of family-based agriculture and the urban informal sector with the capitalist sector of the economy weakens the reach and relevance of macroeconomic policy. In a disaggregated economy, the concepts of aggregate demand and aggregate supply necessarily have a much more restricted purchase. Keynes's multiplier effect of government investment on employment, income and consumption is frustrated by the fact that poor people want to spend much of their additional income on food, and the agricultural sector has a limited capacity to respond to additional demand. Government intervention to expand employment is thus impeded by the existence of an agricultural supply constraint, whose effects are manifested in rising prices rather than increases of real income and employment. Perverse effects are possible. For example, a rise in the money income of agriculturalists may induce them to expand their own food consumption and thereby reduce the size of the surplus that they market to the capitalist sector, with consequent upward pressure on urban food prices. In summary, typically inflation appears before extra government investment has had its desired employment-creating impact.

Does that imply that the government should undertake fiscal expansion, despite accelerating inflation? I do not think so. Inflation certainly can divert extra resources into the hands of the government, but only if it is unanticipated and if it is temporary. After that, higher levels of inflation progressively deter people from holding money, interrupting monetisation of the economy and the growth of financial intermediation, while the resource transfer to the government progressively declines. Conceivably, inflation could be held constant at some level or other, but a constant rate of inflation over a long period is quite pointless. It does not even cause redistribution. It merely complicates everybody's accounting

The macroeconomic problem in a developing country therefore revolves around investing as much as possible as productively as possible in order to promote growth, and particularly in order to relax the agricultural supply constraint, while avoiding inflation. There is an upper limit to investment, but it is set by the country's capacity to borrow. It is a brutal fact about the world financial system that no country's government can, for any length of time, increase its external debt at a rate faster than the rate of growth of its economy. If it tries to do this, sooner or later a debt crisis will intervene. 


\section{Macroeconomic dynamics and economic growth in developing countries}

The neoclassical growth model predicted a convergence of countries' levels of income per capita, while in reality divergence can be observed. When the convergence prediction is made conditional on allowing savings and population growth rates to vary among countries, more than half of the observed divergence in per capita incomes can be attributed to differences in these two variables (Mankiw et al. 1992). Yet this rehabilitation of the neoclassical model is not wholly convincing. Conditional convergence might be the result of structural change, the transfer of resources from a low productivity sector (agriculture) to a high productivity sector (industry), rather than a decline in the marginal product of capital (Thirlwall 2002: 33-4). Since structural change cannot be represented in a one-sector model, one needs to turn to at least a two-sector model to generate a process of economic growth and the transition that produces structural change?

Arthur Lewis's model of economic development with unlimited supplies of labour comprises a capitalist sector (where capitalists hire wage labour) co-existing with a subsistence sector (where labour is not fructified by capital). Growth occurs as capitalists, both private and public, re-invest their profits and draw additional labour out of the subsistence sector at a constant real wage rate somewhat higher than the subsistence wage. This process continues until the labour market in the capitalist sector tightens, and the real wage rate begins to rise, gradually choking off further growth. This kind of dualistic model contains implications for changes in the sector composition of output, the functional distribution of income and urbanisation, assuming that the subsistence sector is rural and the capitalist sector is urban.

The model can be extended to explain the growth of an urban informal sector. The fixed margin by which the capitalist wage exceeds the subsistence wage draws into urban areas job seekers who cannot yet be employed in the capitalist sector. While awaiting their opportunity, they engage in low-capital production or service activities. Open urban unemployment, of the type that is found in developed country labour markets, occurs only when the relatively well off, and often well educated, are able to finance themselves through a period of job search.
However, the Lewis model does not explore the possibility of an agricultural supply constraint, which could lead to a movement of the inter-sector terms of trade against the capitalist sector, reducing its profits and choking off growth. More seriously, like the neoclassical model, the Lewis model assumes that the investment of the capitalist sector is perpetually supply-constrained, so that the generation of its own savings automatically translates into investment. This assumption finesses the question of whether increased purchasing power in the subsistence sector is ever necessary to motivate investment, as some under-consumption theorists have argued. It also forecloses the question how foreign trade stimulates growth, and how exports create additional demand that permits the reaping of economies of scale - a central theme in the work of Nicholas Kaldor and his followers.

\section{Inflation and public expenditure planning in developing countries}

Given the less diversified structure of their economies, developing countries are more exposed to the effects of exogenous shocks from abroad. These can come as rises and falls in the price of export commodities and consequent changes in their terms of trade. Obviously, mono-product exporters will be more vulnerable to income volatility than economies where, as one export price falls, another is rising. So policies of export diversification should provide an antidote in the future. They do not help the immediate policy problem, however. What to do in the meantime? The economy can either be adjusted to the exogenous shock, or not. In the latter case, there will be no problem if the shock is merely temporary, and it quickly neutralises itself. If the shock is not temporary, adjustment can be postponed by increased aid or increased borrowing from abroad. The possibility of increased aid depends on the elasticity of the budgets of foreign governments, while increased foreign borrowing will sooner or later run into the buffers of a debt crisis when the rate of increase of such borrowing exceeds the rate of growth of the economy. When no more aid increases are forthcoming and the limits of foreign borrowing have been reached, adjustment will take place inevitably. The only remaining question is whether the government attempts to manage the adjustment process, or whether it allows it to happen chaotically.

If the government wants to manage the process of adjustment to exogenous shocks, it needs an 
effective framework for planning and implementing its own activities and expenditures, and those of the rest of the public sector. The ability to plan public expenditure effectively is vital for another reason: the composition of public spending influences the degree to which a unit of economic growth benefits the poor. Investment in infrastructure in the subsistence sector, for example, is a key factor in raising agricultural productivity, raising the standard of living and making economic growth pro-poor (World Bank 2005).

Just as in developed countries, it is much easier to plan public expenditure and deliver public services in a context of low inflation. Such planning must be done either in current or in constant prices. If there is inflation and the aim is to control the public sector's demand for real resources, it is a mistake to plan future spending at current prices. Depending on what the rate of inflation eventually turns out to be, totals in current prices might lead to more or less in terms of the use of real resources. However, on the other hand, if spending is planned in terms of constant prices, i.e. having made allowance for a forecast future inflation rate, this suggests that the government intends to be passive in the face of anticipated inflation. Moreover, managing expenditure at constant prices insulates the government from the consequences of its own decisions on the pay of public sector workers. The constant price method of managing expenditure becomes unworkable once annual inflation passes the double-digit level (Pliatzky 1982: 122-75). Only when inflation is kept very low is the difference between current and constant prices negligible, causing the dilemma of whether to plan in current or constant prices to disappear.

Since governments in developing countries do not have discretion to control all areas of public spending, the total of public expenditure should not be the only target, for example to achieve a desired PSBR/GDP ratio. The combination of targeting the total of public expenditure while not being able to control some portion of it can have the perverse result of letting the pressure for more current spending foreclose opportunities for more government investment - say, in rural roads or other agricultural infrastructure - even when cost-benefit analysis indicates that it would be socially profitable. The government must be vigilant to prevent a chronic contraction of the share of public investment to GDP and a crisis of under-investment in public services, which will weaken the impulses of pro-poor growth. One of the main weaknesses of structural adjustment policies in developing countries has been their failure to prevent this happening.

While neoclassical growth models assume that investment is determined simply by the availability of savings, and the Lewis model assumes that domestic capitalists will constantly re-invest from their profits, the Cambridge (UK) vision more realistically argues that the entrepreneurial decisions of large capitalist firms drive the economic system. In the context of globalisation, this means the investment decisions of large multinational corporations. In conjunction with the behaviour of the government, they will be highly influential in determining the quantity and quality of formal employment that gets created in developing countries in the next few decades. In general, and with some exceptions, multinational investment creates modern sector jobs with labour standards that are, though low by Western standards, high by comparison with those prevailing in the domestic rural sector. In the recent past, however, much of their investment has flowed to a relatively small number of middle-income countries, and Africa has been relatively neglected, apart form investments in natural resource extraction industries, which create little employment and tend to have negative effects on the management of the public finances.

What can national governments do to reverse this situation? Much liberalisation of trade and investment regimes has already taken place, and the gains from further moves in this direction may not be great. On the other hand, there are many aspects to maintaining an attractive environment for investment, not least of which is lowering perceptions of business risk. Even in the most attractive environment, however, multinational companies will not invest unless they can identify some particular business opportunity that they wish to pursue. These opportunities will probably be greater if the government can develop, in consultation with its own private sector, an active investment and growth strategy, something that is still possible within the interstices of the WTO trade rules. In the end, however, multinationals will simply invest where they believe they can find the highest risk-adjusted rate of return.

Given that 95 per cent of the world's R\&D is done in the industrial countries, the overall effect of $R \& D$ in 
non-industrial countries depends importantly on whether and how R\&D is transferred to them. If the knowledge produced by R\&D is fully shared when countries trade, levels of income per head will tend to converge, but if R\&D knowledge is not shared, then living standards of the trading countries will progressively diverge. This underlines concerns about poor countries adopting passive technology policies policies of economic stabilisation and liberalisation that merely clear away existing obstacles to flows of trade and foreign investment. Such passive policies, while often an improvement on previous policy regimes, do little to build indigenous capacity to share the technical knowledge embodied in new imports and new FDI. Countries like South Korea and Taiwan that have converged towards industrial country living standards in recent years have certainly not relied on passive technology policies. Neither have they relied solely on trade protection. South Korea in particular developed a strategy of dirigisme, in which institutions to share information between business and government and coordinate plans were stiffened by selective incentives in the form of interest rate subsidies and restrictions on FDI designed to favour domestic firms.

\section{Conclusions}

There are seven main points that need to be emphasised:

1 Right from the start, Keynesian macroeconomics was designed for the specific economic context of the typical developed country. The economy was fully monetised and the workers were wage workers with rights of free collective bargaining and entitlements to social protection against stochastic risks. Its justification for fiscal expansion hardly applies in developing countries having a different economic context - heterogeneity of different forms of employment, and poor articulation between a capitalist and a subsistence sector.

2 In developed countries, the pursuit of the inherently vague objective of full employment, combined with a free wage bargaining system, gradually sparked an inflationary spiral. This undermined the credibility of an employment target for macroeconomic policy, and promoted inflation targeting by an 'independent' central bank. New policy institutions have created a superior environment for the management of public expenditure, including expenditure on social protection.
3 The original dynamic form of Keynes's macroeconomics - the Harrod-Domar model had some unsatisfactory instability features that were eliminated by the Solow-Swan assumption of variable aggregate capital intensity. It remained unclear whether the appropriate capital intensity would be achieved by firms operating in decentralised markets, or by central planning. In either case, what was at issue was the amount of capital with which each worker should be endowed, rather than the quality of their employment.

4 The Solow-Swan model drew forth, in the Cambridge capital controversies of the 1960s, an alternative vision of the functioning of capitalism, which included the idea of a socially stratified labour market and of income generation and distribution being driven primarily by the decisions of large firms - at the global level, by multinational companies.

5 In developing countries, the presence of surplus labour in the subsistence sector and the absence of unemployed non-labour resources together made Keynesian remedies for unemployment largely irrelevant. Additions to government investment rapidly induce inflation without generating extra employment.

6 There are few convincing economic arguments for tolerating more than a very low level of inflation. Effective public expenditure planning is essential if governments are to be able to manage the process of adjusting to external shocks and to pursue a strategy of pro-poor growth. Inflation higher than a few percentage points per year makes the task of planning public spending and public service delivery arbitrary and chaotic.

7 Multinational investment, though large and generally representing a step forward in job quality in the formal sector, is highly concentrated on a few countries and there are no sure-fire methods of attracting it to a particular location. However, within WTO trade rules it is still possible for poor countries to pursue active technology policies through government-private sector cooperation, and success in doing so may be a magnet for foreign direct investment. 


\section{Notes}

1 For a good survey of the different reasons why different countries originally adopted macroeconomic policies, see Hall (1989).

2 I say here 'either/or' to make clear that there are two conflicting interpretations of what Keynes wrote. I might have said 'both/and', because both can be found in different passages of The General Theory. For further discussion, see Laidler 2006: 39-57.

3 The mode of government intervention that Keynes advocated was to initiate public works (building houses, roads, etc.) financed either from new borrowing, or from tax revenue accumulated to pay off the public debt. Neither method necessarily involved running a budget deficit, although deficit financing later became associated in the public mind with Keynesian macroeconomics.

4. Thus Keynes' plea, first made in 1924, for the separate control of the current and the capital budget, was finally realised in the UK in 1997.

\section{References}

Hall, Peter (ed.) (1989) The Political Power of Economic Ideas: Keynesianism Across Nations, Princeton: Princeton University Press

Harrod, Roy F. (1951) 'Notes on Trade Cycle Theory', Economic Journal 61.242: 261-75

Keynes, John Maynard (1978) The Collected Writings of John Maynard Keynes, Vol. VII, London: Macmillan Press

Laidler, David (2006) 'Keynes and the Birth of Modern Macroeconomics', in Roger E. Backhouse and Bradley W. Bateman (eds), The Cambridge Companion to Keynes, Cambridge: Cambridge University Press

Lewis, W. Arthur (1966) Development Planning: The Essentials of Economic Policy, London: George Allen and Unwin

Mankiw, N. Gregory, Romer, David and Weil, David N. (1992) ' $A$ Contribution to the Empirics of
5. Swan suggested that the choice capital intensity could be made centrally by a national planning organisation. (Interestingly, Swan subsequently did work for the Indian Planning Commission, whereas Solow got involved with the American Keynesians who advised President Kennedy.)

6. Joan Robinson lived in India in the mid-1920s, when Austin Robinson was the tutor employed by the Maharajah of Gwalior.

7. It is interesting to note that, when Keynes discussed the Russian economy, which was in his day a developing economy, he did so in terms of the interaction of two sectors - the one-seventh of the population constituting the industrial proletariat and the six-seventh constituting the rural peasantry (Toye 1993: 241-8). The main thrust of his comments was to criticise Soviet government policies of 'urban bias' - achieved by maintaining a dual exchange rate and depreciating the domestic currency by the excessive printing of money.

Economic Growth', Quarterly Journal of Economics 107: 407-38

Pliatzky, Leo (1982) Getting and Spending, Oxford: Basil Blackwell

Robbins, Lionel (1934) The Theory of Wages, London: Macmillan

Robinson, Joan (1962) Economic Philosophy, London: Penguin

Thirlwall, Anthony P. (2002) The Nature of Economic Growth, Cheltenham: Edward Elgar

Toye, John (1993) 'Keynes, Russia and the State in Developing Countries' in Derek Crabtree and A.P. Thirlwall (eds) Keynes and the Role of the State, Basingstoke: Macmillan Press

World Bank (2005) Pro-Poor Growth in the 1990s, Washington DC: World Bank 